\title{
Adsorption of phosphorus by modified clay mineral waste material relating to removal of it from aquatic system
}

\author{
S. Y. N. Jiang ${ }^{1,2}$, L. C. Su ${ }^{1}$, H. D. Ruan ${ }^{1, ~}$, G. F. Zhang ${ }^{1}$, S. Y. Lai ${ }^{3}$, C. H. Lee ${ }^{1}$, C. F. Yu ${ }^{1}$, Z. Wu ${ }^{1}$, \\ X. Chen ${ }^{1}, \mathrm{~S} . \mathrm{He}^{1}$ \\ ${ }^{1}$ Environmental Science Program, Division of Science and Technology, United International College, Beijing Normal University-Hong \\ Kong Baptist University, Zhuhai, Guangdong Province, 519085, P. R. China \\ ${ }^{2}$ School of Environment and Energy, City University of Hong Kong, Sha Tin, Hong Kong \\ ${ }^{3}$ Department of Chemistry, Hong Kong Baptist University, Kowloon Tong, Hong Kong
}

Email address:

hruan@uic.edu.hk (H. D. Ruan)

To cite this article:

S. Y. N. Jiang, L. C. Su, H. D. Ruan, G. F. Zhang, S. Y. Lai, C. H. Lee, C. F. Yu, Z. Wu, X. Chen, S. He. Adsorption of Phosphorus by Modified Clay Mineral Waste Material Relating to Removal of it from Aquatic System. International Journal of Environmental Monitoring and Analysis. Vol. 2, No. 1, 2014, pp. 36-44. doi: 10.11648/j.ijema.20140201.14

\begin{abstract}
This study examined the application of modified clay mineral waste material (MCMWM) for removal of phosphorus (P) from aquatic systems including surface water and wastewater related to the application of recycled solid waste materials. The effects of ionic strength and $\mathrm{pH}$ on $\mathrm{P}$ adsorption by MCMWM were investigated at $\mathrm{pH}$ values of 3, 5, 6,7 and 9 with P concentrations of $10,20,40,100$ and $200 \mathrm{mg} / \mathrm{L}$ in solution. The P adsorption was rapidly at the early stage with $95 \%$ of $\mathrm{P}$ in solution being adsorbed for $10 \mathrm{mg} / \mathrm{L} \mathrm{P}$ in solution at a high $\mathrm{pH}$ range within $0.5 \mathrm{hr}$. The amount of $\mathrm{P}$ adsorbed increased with increasing ionic strength. The amount of $\mathrm{P}$ adsorbed increased continuously as $\mathrm{pH}$ values increased from 3 to 9 for $\mathrm{P}$ adsorption at $10 \mathrm{mg} / \mathrm{L}$. Other series of $\mathrm{P}$ concentrations in solution showed variable trends due to the rates of $\mathrm{P}$ adsorption being affected by $\mathrm{pH}$ associated with the effect of ionic strength. The maximum amounts of $\mathrm{P}$ adsorbed and the highest percentages of $\mathrm{P}$ adsorbed were obtained at $\mathrm{pH} 9$ for all levels of $\mathrm{P}$ concentrations, and at $\mathrm{pH} 7$ for the lower $\mathrm{P}$ concentrations in solution. Calcium (Ca) ion was found to form a bridge for $\mathrm{P}$ adsorption in solution as the increases in the amount of $\mathrm{P}$ adsorbed at high $\mathrm{pH}$ values was related to the performance of $\mathrm{Ca}$ in favoring $\mathrm{P}$ to be adsorbed either onto the surfaces or incorporated into the structural bonds of MCMWM. Ionic strength, $\mathrm{pH}$ and modification process have been found to be the important factors that influenced $\mathrm{P}$ adsorption in solution.
\end{abstract}

Keywords: Ionic Strength, Modified Clay Mineral Waste Material (MCMWM), pH, Phosphorus Adsorption, Recycling of Solid Waste Material

\section{Introduction}

Phosphorus (P) is an essential nutrient in everyday life and a key element for many physiological and biological processes [1]. Phosphorus compounds are present in surface water and domestic wastewater, originating from detergents as well as from metabolism processes, and diffuse runoff from agricultural land. It has been reported that at a concentrations higher than $0.01 \mathrm{mg} / \mathrm{L} \mathrm{P}$ may result in eutrophication [2]. Furthermore, Ruan and Gilkes [3] had found that eutrophication occurred when $P$ concentration in a water system is higher than $0.02 \mathrm{mg} / \mathrm{L}$, thus set up this critical value as the criterion for the evaluation of water eutrophication in Australia. Based on the chemical bonding and formation of $\mathrm{P}$ in the environment, it can be divided into iron-phosphate (Fe-P), aluminium- phosphate (Al-P), and calcium- phosphate (Ca-P), as well as those bound or adsorbed by organic matter (O-P).

The increase of $\mathrm{P}$ in wastewater is one of the main factors of eutrophication and level causes in Biochemical Oxygen Demand (BOD) and Chemical Oxygen Demand (COD) in rivers and lakes [4]. Many water bodies everywhere in the world are experiencing an increasing number of algal blooms due to eutrophication, which reduces the amenity value and ecological health of water bodies such as lakes, slow mobbing rivers and drinking water reservoirs [2]. The amount of $\mathrm{P}$ is now being controlled by legislation on discharge limits in many counties. With concerning the increase of $\mathrm{P}$, further processing to reduce the quantity of $\mathrm{P}$ in wastewater is demanded [4]. 
The modified clay mineral waste material (MCMWM) was used for $\mathrm{P}$ adsorption in this study. The physical, chemical and mineralogical properties, particularly the surface and structure properties to characterize environmental significance, relating to the capacity and potential application of MCMWM in adsorption of heavy metals have been investigated [5-6]. The MCMWM contains layer silicate minerals (Fig. 1), and the mineral properties were reported elsewhere [5]. It has been reported that three types of surface structures have been found in the layer silicates [7]. For the type I structure, for example in kaoline, one basal plane consists of a hexagonal or ditrigonal arrangement of siloxane rings, i.e. all surface $\mathrm{O}$-atoms are doubly coordinated to $\mathrm{Si}$, which itself is in fourfold coordination with $\mathrm{O}$. Type II structures are represented in the opposite basal plane composed of a slightly open hexagonal array of $\mathrm{OH}$ groups doubly coordinated to $\mathrm{Al}$, which is itself in sixfold coordination with $\mathrm{OH}$ and $\mathrm{OSi} / 4$ groups. Finally, type III structures are represented by $\mathrm{O}(\mathrm{OH})$ groups exposed along the edges of the clay platelets, and these are singly, doubly, or triply bonded to the $\mathrm{Al}$ and/ or $\mathrm{Si}$ atoms of the octahedral and tetrahedral sheets [7].

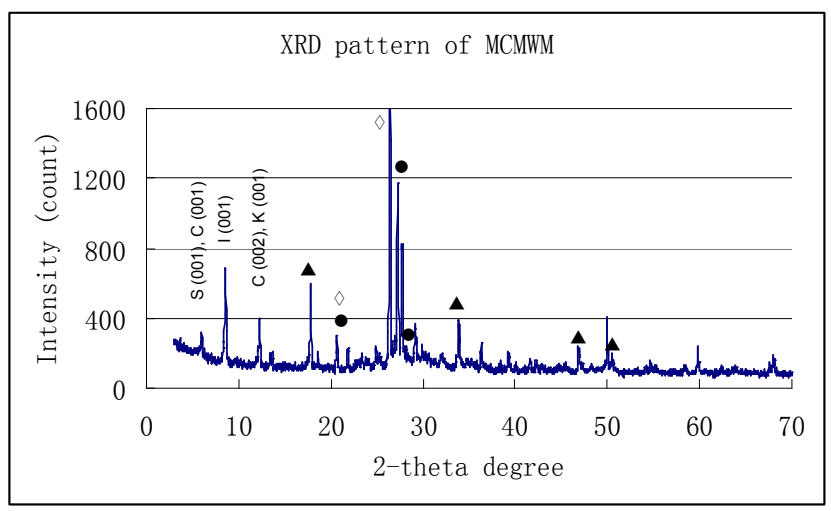

Figure 1. XRD pattern of MCMWM between 3-70 20; S: smectite, $C$ : chlorite, I: illite, $\mathrm{K}$ : kaolin, $\boldsymbol{\Lambda}: \mathrm{Ca}(\mathrm{OH})_{2}, \diamond:$ quartz, •: feldspars

Type I surfaces tend to be very inert where there is a full balance of charge, i.e. when the lattice substitutions are absent. In cases where isomorphous substitution takes place in the tetrahedral or octahedral sheets to give rise to local deficits of positive charge, the ditrigonal hole structure is transformed into a hard Lewis base [8]. Surface charge compensation then takes place through adsorption of cations, largely in the forms of outer sphere complexes, and there is non-preferential adsorption of counter ions in the diffuse layer. The type II Surface is comparatively inert. This surface, especially when it arises from aluminum species, remains electrically neutural at the $\mathrm{pH}$ values which predominate in the soil. The type III surfaces, consisting of edge $\mathrm{O}(\mathrm{OH})$ group, are much different. A local deficit in the charge compensation of the $\mathrm{O}$ atom at the 'fractured' edges, due to the 'broken bonds', leads to a $\mathrm{pH}$-dependent charge following adsorption/desorption of protons [7]. The 1:1 clay minerals which do not have isomorphous substitution in the lattice structures, are non-expanding because of hydrogen bonding between alternating type I and II basal surfaces. Its surface properties are largely dominated by the type III groups at the edges. In contrast, the 2:1 layer clays possess only siloxane (type I) basal surfaces, and thus expose type I hexagonal arrays on both sides of the interlayer. In the absence of isomopous substitution within the layers, such as for pyrophyllite, the layer are non-expanding since the siloxane surface reacts only weakly with water, and may be considered to be essentially hydrophobic. When isomorphous substitution takes place in the octahedral layer, for example $\mathrm{Mg}^{2+}$ for $\mathrm{Al}^{3+}$ in dioctahedral montmorillonite, the charge deficit which results in relative and uniform delocalization over the surface oxygens. Where isomorphous substitution takes place in tetrahedral sheet, such as $\mathrm{Al}^{3+}$ for $\mathrm{Si}^{4+}$ in illite, the charge on the three surface plane oxygen atoms coordinated to the substituent is greater than that on oxygens coordinated to silicon, and hence the charge distribution on the surface plane is less homogeneous than that for montmorillonite. Thus, the substantial differences in adsorption preferences for various ions exhibited by different clay minerals may be traced to the location and the extent of the isomorphous substitution, and to the hardness of the Lewis base sites that result [7].

Because of the dynamics, fate and transport of $\mathrm{P}$ in the environment attributed to its adsorption, $\mathrm{P}$ can play a significant role in water quality [3]. Phosphorus adsorption has been reported to be affected by a number of factors, including $\mathrm{pH}$ [9-11], ionic strength [12-13], type of minerals [14], organic matter content [15], and various forms of $\mathrm{Fe}$ and $\mathrm{Al}$ [15]. Among these factors the effect of $\mathrm{pH}$ on phosphorus sorption is probably the least understood [16-18]. While some reports have known that phosphorus sorption decreased with increase in $\mathrm{pH}$ in the acidic $\mathrm{pH}$ range [19-20], others have shown that phosphorus sorption increased with increase in $\mathrm{pH}$ [21-22]. There is also some evidence to show that phosphorus sorption decreased with increase in $\mathrm{pH}$ up to 5.0-6.0, beyond which it increased to be due largely to the difference in the exchangeable $\mathrm{Al}$ values of the soils [17, 23], whereas Barrow [17] cites at least six factors to be responsible. In the experiment from Eze and Loganathan [24], they found the results of quantity of the $P$ adsorption under the different effects including ionic strength and $\mathrm{pH}$.

This study dealt with the P adsorption by MCMWM at a wide range of $\mathrm{pH}$ values from 3 to 9 , and in the various $\mathrm{P}$ concentrations in solution. The effects of ionic strength, $\mathrm{pH}$, and modification process of MCMWM were investigated to interpret the relationships among those factors.

\section{Materials and Methods}

The modified clay mineral waste material (MCMWM) was supplied by a commercial company, which has been modified through physical and chemical processes in order to obtain a high porosity surface and an affinitive adsorbent The MCMWM was finally treated by passing a sieve to obtain the powder with particle size of $\leqq 0.075 \mathrm{~mm}$. The 
physical, chemical and mineralogical properties of MCMWM had been investigated and reported earlier [5-6].

A stock $\mathrm{P}$ standard solution $(1000 \mathrm{mg} / \mathrm{L})$ was firstly prepared by weighing $4.394 \mathrm{~g}$ of $\mathrm{KH}_{2} \mathrm{PO}_{4}$ crystals into a beaker and dissolving with little amount deionic (DI) water. The dissolved $\mathrm{P}$ solution was poured into a $1000 \mathrm{ml}$ volumetric flask, and diluted to the mark with DI water. This $\mathrm{P}$ stock solution was used for making various concentrations for P adsorption.

The adsorption of $\mathrm{P}$ experiment was carried out following up the procedures below: (1) Various concentrations of $\mathrm{P}$ were firstly prepared by using the 1000 $\mathrm{mg} / \mathrm{L}$ stock solution. $2,4,8,20$, or $40 \mathrm{ml}$ of $1000 \mathrm{mg} / \mathrm{L}$ stock solution was respectively pipetted into a $100 \mathrm{ml}$ of volumetric flask, and diluted to mark with DI water. The P concentrations of the series for adsorption were corresponding to $20,40,80,200,400 \mathrm{mg} / \mathrm{L}$ in solutions. (2) $0.1 \mathrm{~g}$ (accurate to $0.0001 \mathrm{~g}$ ) subsample of MCMWM was respectively weighed into a $50 \mathrm{ml}$ tube. Then $20 \mathrm{ml}$ of DI water was added to wet the solid sample, and the $\mathrm{pH}$ of solution was adjusted to remain at decided $\mathrm{pH} 3,5,6,7,9$ by dropping either $\mathrm{HCl}$ or $\mathrm{NaOH} .25 \mathrm{ml}$ of various concentrations of $20,40,80,200,400 \mathrm{mg} / \mathrm{L}$ of $\mathrm{P}$ solution was added into each tube containing subsample, and DI water was added to mark up the mark of $50 \mathrm{ml}$. The accurate concentration of $\mathrm{P}$ in the solution was 10, 20,40, 100 and $200 \mathrm{mg} / \mathrm{L}$, respectively. The tubes were placed in a horizontal shaker to shake at a speed of $200 \mathrm{rpm}$ at a temperature of $25^{\circ} \mathrm{C}$ for $0.5 \mathrm{hr}$. (3) The samples after shaking were filtered to obtain clear supernatants. $35 \mathrm{ml}$ of clear solution was pippetted into a $50 \mathrm{ml}$ volumetric flask and $10 \mathrm{ml}$ of Vanadate-molybdate reagent was added. After that, the solutions were diluted with DI water to the mark. After 20 mins the concentrations of $\mathrm{P}$ in the solutions were determined using a Vis spectrophotometer versus a blank at a wavelength of $470 \mathrm{~nm}$. The procedures (2) and (3) were repeated for different $\mathrm{pH}$ values at $3,5,6,7,9$.

\section{Results and Discussion}

\subsection{Adsorption of P Relating to P Concentration in Solution}

To describe the process of $\mathrm{P}$ adsorption, the amount of $\mathrm{P}$ adsorbed per gram MCMWM was used for the evaluation of the capacity for $\mathrm{P}$ adsorption onto MCMWM. The amounts of $\mathrm{P}$ adsorbed per gram MCMWM at various $\mathrm{pH}$ values increased with the increase in $\mathrm{P}$ concentrations in solution except a couple of samples, e.g. $40 \mathrm{mg} / \mathrm{L}$ at $\mathrm{pH} 3$ and $100 \mathrm{mg} / \mathrm{L}$ at $\mathrm{pH} 6$ (Table 1). It is noted that when the ionic strength of $\mathrm{P}$ increased in solution, the reaction tend to favor $\mathrm{P}$ to enter the affinitive adsorption sites, thus leading the reaction towards the formation of $\mathrm{P}$ complex on MCMWM surfaces [25]. A basic concept of $\mathrm{P}$ adsorption introduced by Kuo and Lotse [26] is that, when a P ion in solution is brought in contact with the surface, and activated complex is formed. This transition site can be identified as the configuration of the system at the maximum of the potential energy barrier [27]. The rate of reaction is the number of $\mathrm{P}$ ions passing over the potential energy barrier per unit time. As noticed in this experiment, the $\mathrm{P}$ adsorption reaction was rapid at the early stage of contact between $\mathrm{P}$ ions and the affinitive sites of adsorbent, e.g. the MCMWM surfaces. In particular for the $\mathrm{P}$ adsorption at lower concentrations, for instance, the percentage of $\mathrm{P}$ adsorption could reach up to $95 \%$ within half an hour when the $\mathrm{P}$ concentrations were between 10 and $40 \mathrm{mg} / \mathrm{L}$. (Table 2).

Table 1. Amounts of $P$ adsorbed per gram MCMWM at various $p H$ values

\begin{tabular}{cccccc}
\hline $\begin{array}{c}\text { P in solution } \\
(\mathbf{m g} / \mathbf{L})\end{array}$ & \multicolumn{5}{c}{ P adsorbed per gram MCMWM at various $\mathbf{p H}$} \\
values (mg/g)
\end{tabular}

Table 2. Percentage of $P$ adsorbed in solution at various $p H$ values

\begin{tabular}{cccccc}
\hline $\begin{array}{c}\text { P in solution } \\
(\mathbf{m g} / \mathbf{L})\end{array}$ & \multicolumn{5}{c}{ P adsorbed from solution at various $\mathbf{p H}$ values } \\
$\mathbf{( \% )}$
\end{tabular}

Because the $\mathrm{P}$ adsorption rate was high at the initial period of time of contact, followed by a decreasing trend as the adsorption was in progress [25], such decrease in the rate could be due to the reversible reaction, that is the desorption occurred along with the adsorption process. A change in the rate as the function of time determined the different adsorption performance at various levels, and this reversibility may possibly occur over a very long time [28]. An increasing $\mathrm{P}$ concentration in solution therefore resulted in the changes not only in abundance of $\mathrm{P}$ ions, as a consequence to increase the ionic strength in favoring $\mathrm{P}$ adsorption, but also in the increase in the amount of $\mathrm{P}$ desorbed from those already being adsorbed onto the surfaces of an adsorbent, at different states of equilibrium [25]. The adsorption performance of the present work did not exactly follow this pathway due to the adsorption experiments being conducted at a short period of time, which may not be in a full equilibrium state, or under a non-equilibrium condition. Ryden et al. [29] reported that 
the amounts of inorganic P adsorbed by soil-like materials were affected by ionic strength and cation species of the matrix solution. They emphasized that particularly for non-equilibrium conditions the amounts of $\mathrm{P}$ adsorbed increased with increasing ionic strength. Ryden and Syers [30-31] also demonstrated that the effects of ionic strength on $\mathrm{P}$ adsorption was kinetic for $\mathrm{P}$ additions where chemisorption dominated overall adsorption but became absolute at higher $\mathrm{P}$ additions where a more physical, potential-determining (p.d.) adsorption mechanism accounted for an appreciable proportion of the overall amount of $\mathrm{P}$ adsorbed. Naidu, et al., [32] had observed that, depending on the $\mathrm{pH}$, increasing ionic strength can either decrease or increase $\mathrm{P}$ adsorption. These phenomena had also been found in this work, indicating that the decreases in $\mathrm{P}$ adsorption with the increase in ionic strength were performed between 20 and $40 \mathrm{mg} / \mathrm{L}$ at $\mathrm{pH} 3$ and between 40 and $100 \mathrm{mg} / \mathrm{L}$ at $\mathrm{pH} 6$, while the increase in $\mathrm{P}$ adsorption with the increase in ionic strength was performed by all the rest concentrations (Table 1 ).

One of the remarkable phenomena observed in this study was that there was hysteresis or delay of $\mathrm{P}$ adsorption at all $\mathrm{pH}$ levels used, and the hysteresis appeared in $40 \mathrm{mg} / \mathrm{L}$ for pH 3 (Fig. 2a), and in $100 \mathrm{mg} / \mathrm{L}$ for $\mathrm{pH} \mathrm{5,} 6$ and 7 (Figs. 2b, $2 \mathrm{c}$ and $2 \mathrm{~d}$ ), with the exception for $\mathrm{pH} 9$ that exhibited almost a straight line (Fig. 2e). These phenomena were revealed by those reductions in percentage of $\mathrm{P}$ adsorption from the corresponding $\mathrm{pH}$ values and $\mathrm{P}$ concentrations in solution (Table 2). This finding suggested that at the early stage, $\mathrm{P}$ adsorption was in the non-equilibrium state. $\mathrm{P}$ adsorption performed in several degrees depending upon ionic strength, $\mathrm{pH}$ and adsorption functions including physisorption and chemisorptions that related largely to the surface and structural characteristics of an absorbent (i.e. MCMWM) [5-6, 25, 33-35].

Another reason for hysteresis or delay of $\mathrm{P}$ adsorption may be the effect of $\mathrm{pH}$ since the hydrogen or hydroxyl in solution contributed to either favor or block $\mathrm{P}$ adsorption, in conjunction with the effect of $\mathrm{P}$ ionic strength. Furthermore, the adsorption of $\mathrm{P}$ onto the MCMWM could be complicated because the surfaces of MCMWM had been modified in order to create pores including nanometer-size micropores and defects within crystals for increasing the capacity of adsorption [5-6, 33, 36-37]. The effects of $\mathrm{pH}$ and modification process will be discussed later

The amount of $\mathrm{P}$ adsorbed by MCMWM varied as affected by different $\mathrm{pH}$ values. At the low concentration of $\mathrm{P}$ solution, e.g. $10 \mathrm{mg} / \mathrm{L}$, the amounts of $\mathrm{P}$ adsorbed increased from $2.15 \mathrm{mg} / \mathrm{g}$ to $4.88 \mathrm{mg} / \mathrm{g}$ with the increasing values of $\mathrm{pH}$ from 3 to 9 (Table 1 and Fig. 3-a). However, this trend did not apply to the rest concentrations of $\mathrm{P}$ in solution used in this experiment. It is assumed that the effect of $\mathrm{pH}$ on $\mathrm{P}$ adsorption tended to be associated with the $\mathrm{P}$ concentration in solution, as this may be the combined effects from both cation and anion in solution $[6,38]$.
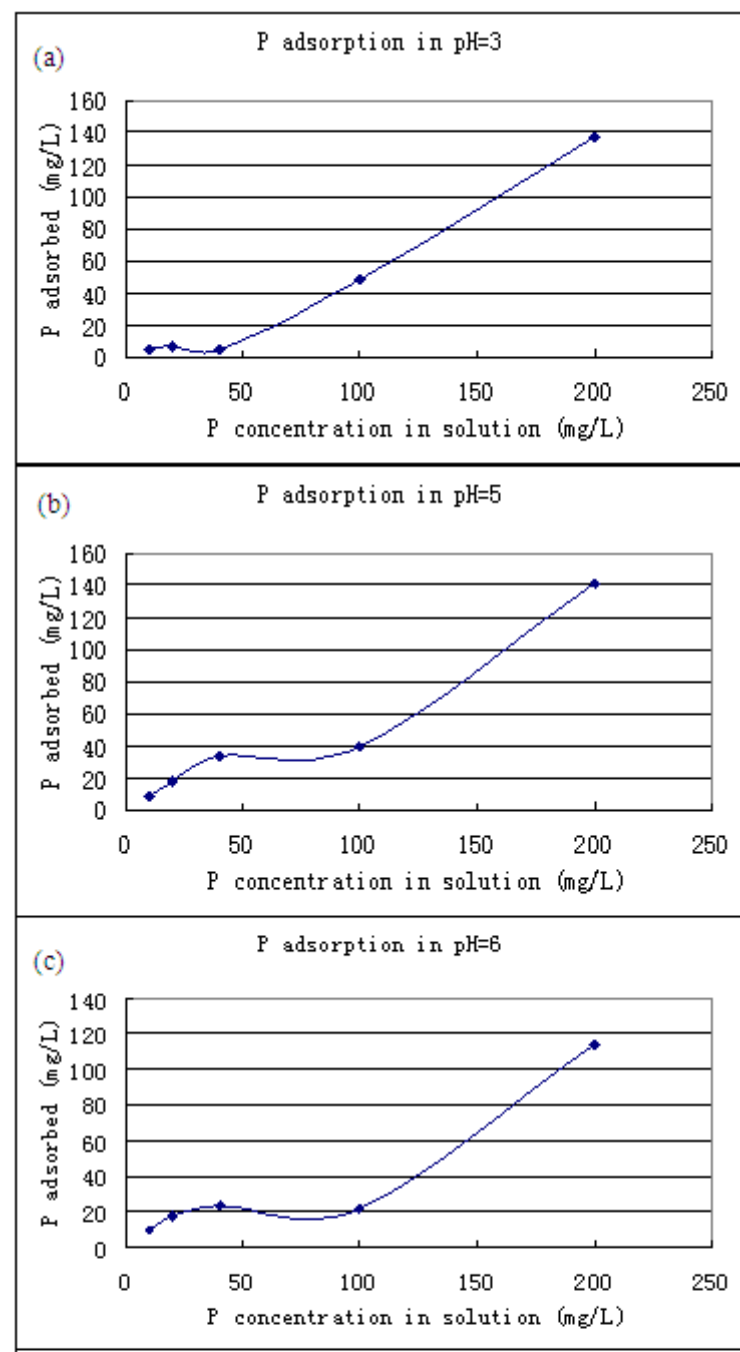

(d) $\quad \mathrm{P}$ adsorption in $\mathrm{pH}=$ ?
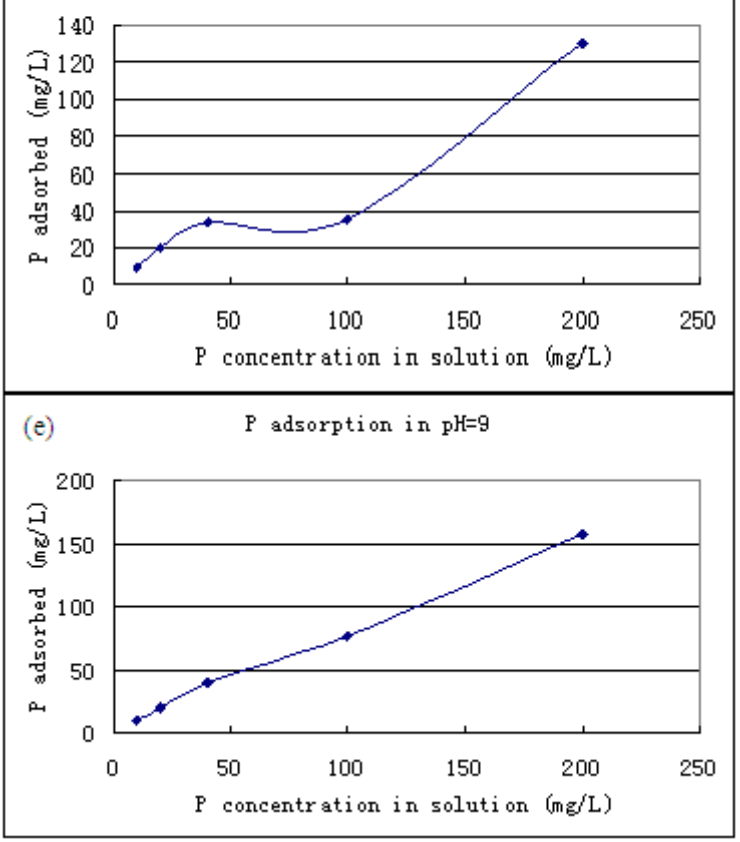

Figure 2. The amount of $P$ adsorbed vs. $P$ concentration in solution at (a) pH 3, (b) pH 5, (c) pH 6, (d) $p H 7$ and (e) $p H 9$. 


\subsection{Effect of pH on P Adsorption}

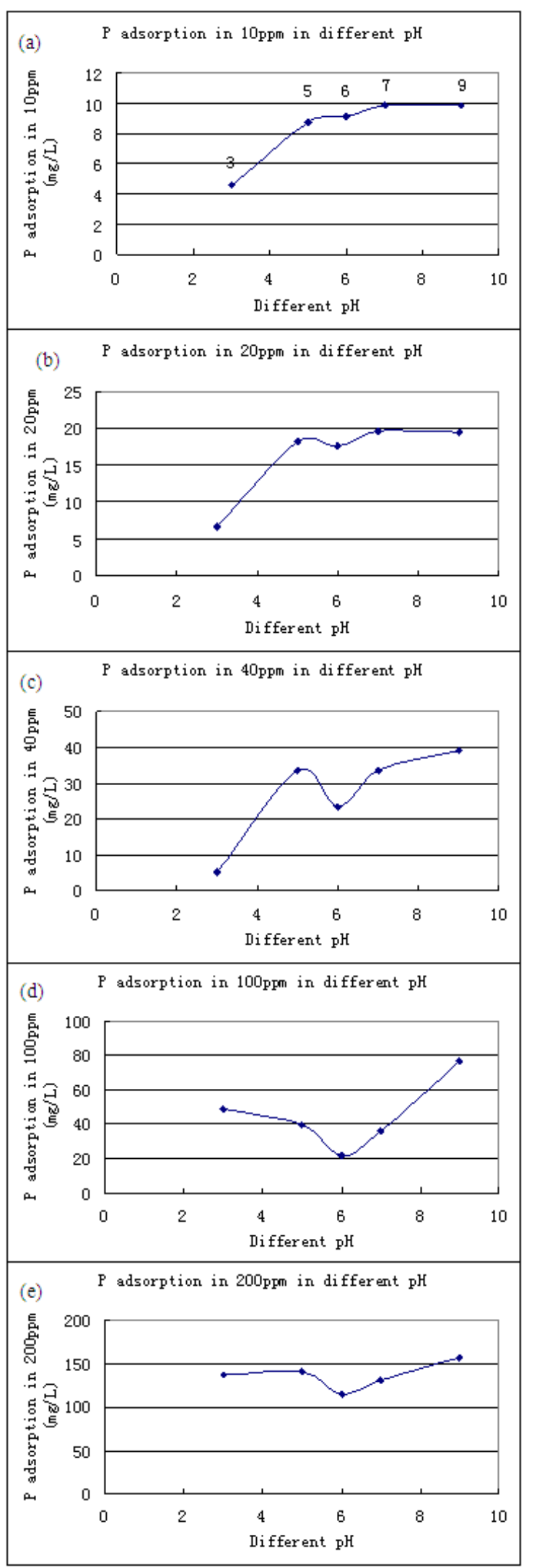

Figure 3. $P$ adsorbed in the same concentration versus various $p H$ values; (a) $10 \mathrm{mg} / \mathrm{L}$, (b) $20 \mathrm{mg} / \mathrm{L}$, (c) $40 \mathrm{mg} / \mathrm{L}$, (d) $100 \mathrm{mg} / \mathrm{L}$, and (e) $200 \mathrm{mg} / \mathrm{L}$.
The lowest absorption values of $\mathrm{P}$ adsorption in solution were detected at $\mathrm{pH} 3$, whereas the highest ones were at $\mathrm{pH}$ 9 (Table 1 and Fig. 3). There was a decrease in P adsorption at $\mathrm{pH}$ values between 5 and 6 for all levels of $\mathrm{P}$ concentrations in solution except for the $10 \mathrm{mg} / \mathrm{L}$ (Fig. 3a). For the $100 \mathrm{mg} / \mathrm{L}$, the amounts of $\mathrm{P}$ adsorbed decreased from $\mathrm{pH} 3$ to $\mathrm{pH} 6$ and increased from $\mathrm{pH} 6$ to $\mathrm{pH} 9$, showing a "V" shape in adsorption curve (Fig. 3d).

The percentages of $\mathrm{P}$ adsorption in solution at various $\mathrm{pH}$ values are plotted in Figure 4. The lowest percentage of $\mathrm{P}$ adsorption was determined from the $40 \mathrm{mg} / \mathrm{L}$ sample at $\mathrm{pH}$ $3,100 \mathrm{mg} / \mathrm{L}$ for all other $\mathrm{pH}$ values (Fig. 4). It is assumed that the percentage of $\mathrm{P}$ adsorption would decrease as the concentration of $\mathrm{P}$ in solution increased due to more $\mathrm{P}$ ion left in solution. The results of this study showed some variations in the percentage of $\mathrm{P}$ adsorption, which did not follow the hypothesis as described earlier (Table 2). This is again indicated that the percentage of $\mathrm{P}$ adsorption was governed by both the $\mathrm{P}$ concentrations and $\mathrm{pH}$ values, which were the combined effects of cation and anion.

The experimental data of this study showed that the $\mathrm{P}$ adsorption was favored under the alkaline conditions. Both the amount of $\mathrm{P}$ adsorbed per gram MCMWM and the percentage of $\mathrm{P}$ adsorbed in solution exhibited the highest average values at $\mathrm{pH} 9$ (Tables 1 and 2). Since MCMWM carried both positive and negative charges in various ranges of $\mathrm{pH}$ values, the negative charge increased with increasing $\mathrm{pH}$ and the positive charge increased with decreasing $\mathrm{pH}$. This co-existence of positive and negative charges is in consistence with the results reported in previous works, who proposed that positive and negative charges are spatially separated on solid particles [13, 39-40]. Barrow [41] had employed a four plane model for the adsorption of ion on a variable charged surface, explained that at high $\mathrm{pH}$ the surface charge is negative and that a high concentration of electrolyte causes a high number of electrolyte cations in the outer planes of adsorption, thus decreases the negative potential on the surface resulting in increased $\mathrm{P}$ adsorption. Bolan et al. [13] found that $\mathrm{P}$ adsorption in the soil increased between $\mathrm{pH} 3$ and 4, and decreased up to $\mathrm{pH} 6$ or 7 depending on the adsorbent matrixes. They also found that in some soil samples the amount of $\mathrm{P}$ adsorbed increased again when $\mathrm{pH}$ values changed from 6 to 8 . The results of this study were partially consistent with their findings at the low $\mathrm{pH}$ range and the increasing trend of $\mathrm{P}$ adsorption was related to the increasing $\mathrm{pH}$ values under the alkaline conditions. Moreover, the maximum amount of $\mathrm{P}$ adsorbed by MCMWM was exhibited at $\mathrm{pH} 9$ whereas that of the results of Bolan et al. [13] was at $\mathrm{pH} 4$. Similar increases in $\mathrm{P}$ adsorption at high $\mathrm{pH}$ values have frequently been ascribed to the precipitation of calcium phosphorus because of the high levels of calcium existed [42], and as the case of the present samples containing certain amounts of Ca-minerals [5], to the formation of highly reactive polyhydroxides [43], or to the specific effect of calcium on phosphorus adsorption [44-46]. 


\subsection{Effect of Modification Process on P Adsorption}

In order to increase the adsorption capacity, the MCMWM samples had been physically and chemically modified. It was expected that modification process would increase the specific surface areas and the surface and structural defects that may play as the affinitive sites of $\mathrm{P}$ adsorption. The modified MCMWM material used in this study was provided by a commercial company and previously modified through physical and chemical processes. Prior to this study, the physical, chemical and mineralogical properties of the modified MCMWM materials have been investigated using BET technique for specific surface area and pore size distribution measurements, ICP-MS for heavy metal analysis, X-ray diffraction (XRD) for mineral component determination, scanning electron microscopy coupled with energy dispersive X-ray analysis (SEM-EDX) for crystal morphology and elemental distribution, and Fourier transform infrared spectroscopy (FTIR) for mineral surface property examination [5].

After the modification processes, the particle of MCMWM became smaller with rough surfaces and structural defects. Micro-, meso-, and macro-pores, as well as voids, which contribute to the increase in specific surface area, were observed to be developed [5]. An increase in specific surface area has been reported to be related highly to the decrease in particle or crystal size [33], and the specific surface area is the most important factor in controlling the kinetic $\mathrm{P}$ adsorption [25]. The mineral compositions and surface/structural defects are also important factors that affect the P adsorption [25, 47-49]. Since modification processes had increased the specific surface area, structural and surface defects, and developed micropores in MCMWM. It has been reported that the most reactive sites on a surface are associated with corners, edges, and lattice disturbances [50]. Previous work has indicated that positive edge charges are probably the sites responsible for adsorption and are attributed to the exposed cation atoms (e.g. $\mathrm{Al}^{3+}$ and $\mathrm{Si}^{4+}$ ) on the edge face of the crystal [51-52]. The MCMWM contains clay- and metalminerals, and the metal oxides and clay minerals have been reported as the strong adsorbers of phosphorus ion in solution [53-57].

One of the important components in MCMWM is the Ca-contained minerals. It has been found that calcium played a significant role in influencing the chemisorptions at different $\mathrm{pH}$ values [24]. At the $\mathrm{pH}$ range of 5.0-6.0 the increase in $\mathrm{P}$ adsorption can be attributed to the formation of basic calcium phosphorus complex at the surface of col loid [44, 58-59] and to the formation of precipitates of these compounds in solution at $\mathrm{pH}$ values near neutral [60]. Calcium ion is specifically adsorbed on oxide and clay surfaces at $\mathrm{pH}$ values above 6.0 , and it helps the adsorption of $\mathrm{P}$ by forming the surface complexes of basic calcium phosphorus at high concentrations of $\mathrm{Ca}^{2+}$ [61-62], thus $\mathrm{Ca}^{2+}$ fits in the cavity between two adjacent $\mathrm{P}$ ions and as a result reducing the electrostatic repulsion between the negatively charged ions, allowing more $\mathrm{P}$ to be adsorbed [24]. The results of the present study are in agreement with what have been intensively discussed by a number of researchers.

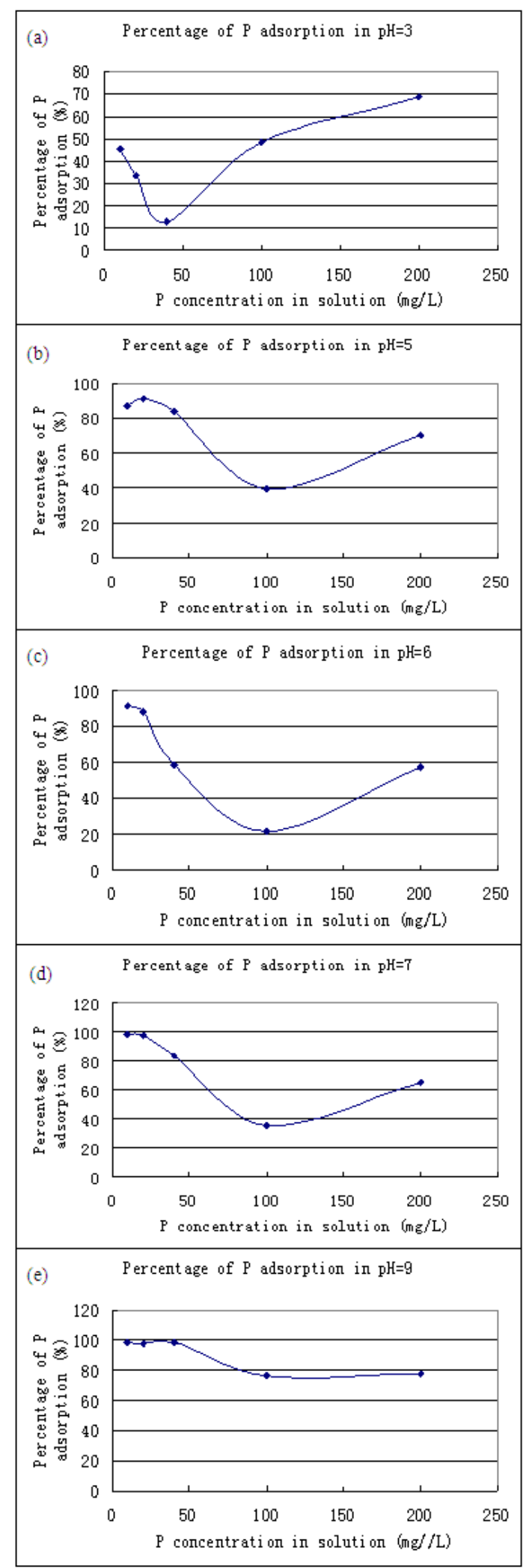

Figure 4. $P$ adsorbed in the same concentration versus various $p H$ values; (a) $10 \mathrm{mg} / \mathrm{L}$, (b) $20 \mathrm{mg} / \mathrm{L}$, (c) $40 \mathrm{mg} / \mathrm{L}$, (d) $100 \mathrm{mg} / \mathrm{L}$, and (e) $200 \mathrm{mg} / \mathrm{L}$. 


\section{Conclusion}

Phosphorus adsorption can be affected by a number of factors. The ionic strength, $\mathrm{pH}$ and modification process of MCMWM were studied in order to understand the relationships among these factors and their multi-effects on $\mathrm{P}$ adsorption by MCMWM. The findings of this research can be concluded as the following. (a) The amounts of $\mathrm{P}$ adsorbed increased with increasing $\mathrm{P}$ ionic strength. (b) When the $\mathrm{P}$ ionic strength increased in solution, the reaction tend to favor $\mathrm{P}$ to enter the affinitive adsorption sites, thus leading the reaction towards the formation of $\mathrm{P}$ complex on surfaces of an adsorbent. (c) $\mathrm{P}$ adsorption reaction was rapidly at the early stage of contact between $P$ ions and the affinitive sites of an adsorbent, e.g. the MCMWM surfaces. (d) At the early stage, that was in the non-equilibrium state, $\mathrm{P}$ adsorption performed in several degrees depending upon ionic strength, $\mathrm{pH}$ and adsorption functions including physisorption and chemisorptions that related largely to the surface and structural characteristics of an absorbent (i.e. MCMWM). (e) The effect of $\mathrm{pH}$ on $\mathrm{P}$ adsorption was associated with the $\mathrm{P}$ concentration in solution, as they are the combined effects from both cation and anion in solution. (f) $\mathrm{P}$ adsorption by MCMWM was favored under alkaline condition. (g) Increase in $\mathrm{P}$ adsorption at high $\mathrm{pH}$ values was due to the precipitation of calcium phosphorus because of the high levels of calcium existed to build an adsorption bridge between $\mathrm{P}$ ion and the surfaces of an adsorbent. (h) Modification process had increased the specific surface area, structural and surface defects, and developed internal and external pores in MCMWM, thus increased the capacity of $P$ adsorption. The results of this work revealed the potential of its application for the removal of $\mathrm{P}$ in aquatic system

\section{Acknowledgements}

This work is financially supported by the Beijing Normal University-Hong Kong University, United International College (UIC) under research projects R201101 and R201208.

\section{References}

[1] I. Steen, Phosphorous availability in the 21st century; Management of a nonrenewable resource. J. Phosphorus Potassium, Nr. 217, Sept. - Oct., 1998.

[2] H. Bernhardt, Phosphor-Wege und Verbleib in der Bundesrepublik Deutschland. Verlag Chemie Weinheim, New York, 1978.

[3] H.D. Ruan, R.J. Gilkes, Accumulation of phosphorus in farm ponds and dams in South-Western Australia. J. Environ. Qual. 29, 1875-1881, 2000.

[4] Y. Watanabe, H. Yamada, T. Kasama, J. Tanaka, Y. Komatsu, Y. Moriyoshi, Adsorption behavior of phosphorus on synthetic boehmites. Proceedings of the 19th International Japan-Korea Seminar on Ceramics, pp. 80-84, 2002.
[5] Y.N. Jiang, H.D. Ruan, S.Y. Lai, C.H. Lee, C.F. Yu, Z. Wu, X. Chen, S. He, Recycling of solid waste material in Hong Kong: I. Properties of modified clay mineral waste material and its application for removal of cadmium in water. Earth Science, 2, 40-46, 2013.

[6] Y.N. Jiang, Effects of Ionic Strength and $\mathrm{pH}$ on Phosphorus Adsorption by Modified Clay Mineral Waste Material. Honours Degree Final Year Project II. Environmental Science Program, Division of Science and Technology, Beijing Normal University-Hong Kong Baptist University United International College, 2009.

[7] M.H.B. Hayes, G.H. Bolt, Soil colloids and the soil solution. In G.H. Bold et al. (Eds.), Interactions at the Soil Colloid Soil Solution Interface. NATO Science Series E, Plenum, New York and London. pp 1-33, 1990.

[8] A.C.C. Newman, M.H.B. Hayes, Some properties of clays and of other soil colloids and their influences on soils. In M.F. De Boodt, M.H.B. Hayes, A. Herbillon, E.B.A. De Strooper and J.J. Tuck (Eds.), Soil Colloids and Their Associations in Aggregates. Plenum, New York and London. pp 39-55, 1990.

[9] D. Lopez-Hernandez, C.P. Burnham, The effect of $\mathrm{pH}$ on phosphorus adsorption in soils. J. Soil Sci. 25, 207-216, 1974.

[10] [10] U. Mokwunye, The influence of $\mathrm{pH}$ on the absorption of phosphorus by soil from Guinea and Sudan savannah zones of Nigeria. Soil Sci. Soc. Am. Proc. 39, 1100-1102, 1975.

[11] R.E. White, A.W. Taylor, Effect of $\mathrm{pH}$ on phosphorus adsorption and isotopic exchange in acid soils at low and high additions of soluble phosphorus. J. Soil Sci. 28, 48-61, 1977.

[12] J.C. Ryden, J.K. Syers, Rationalisation of cation and ionic strength effects on P sorption by soils. J. Soil Sci. 26, 395-406, 1975.

[13] N.S. Bolan, J.K. Syers, R.W. Tillman, Ionic strength effects on surface charge and adsorption of phosphorus and sulphate by soils. J. Soil Sci. 37, 379-388, 1986

[14] [14] A.S.R. Juo, R.L. Fox, Phosphorus sorption characteristics of some bench-mark soils of West Africa. Soil Sci. 124, 370-376, 1977.

[15] P. Loganathan, M.J. Hedley, Downward movement of cadmium and phosphorus from phosphatic fertilizers in a pasture soil in new Zealand, Environ. Pollution, 95, 319-324, 1997.

[16] [16] N.J. Barrow, Modelling the effects of $\mathrm{pH}$ on phosphorus sorption by soil. J. Soil Sci. 35, 283-297, 1984.

[17] N.J. Barrow, Reactions with variable-charged soils. Fert. Res. 14, 1-100, 1987.

[18] I.R. Willett, C.J Chartres, T.T. Nguyen, Migration of phosphorus into aggregated particles of ferrihydrite. J. Soil Sci. 39, 275-282, 1988.

[19] R.L. Parfitt, Phosphorus adsorption on an ozasol. Soil Sci. Soc. Am. J. 41, 1064-1967, (1977).

[20] D.K. Friesen, A.S.R. Juo, M.H. Miller, Liming and lime-phosphorus-zinc interactions in two Nigerian Ultisols: I. Interactions in the soil. Soil Sci Soc Am J. 44, 1221-1226, 1980. 
[21] S.L. Amarasiri, S.R. Olsen, Liming as related to solubility of $\mathrm{P}$ and plant growth in an acid tropical soil. Soil Sci Soc Am J. 37, 716-721,1973;

[22] U. Mokwunye, The influence of $\mathrm{pH}$ on the adsorption of phosphorus by souls from the Guinea and Sudan Savannah Zones of Nigeria. Soil Sci Soc Am J. 39, 1100-1102, 1975

[23] J.T. Sims, B.G. Ellis, Changes in phosphorus adsorption associated with aging of aluminum hydroxide suspensions. Soil Sci Soc Am J. 47, 912-916, 1983

[24] O.C. Eze, P. Loganathan, Effects of $\mathrm{pH}$ on Phosphorus sortion of some paleudults of southern Nigeria. Soil Sci. 150, 613-621, 1990.

[25] H.D. Ruan, R.J. Gilkes, Kinetics of phosphorus sorption and desorption by synthetic aluminous goethite before and after thermal transformation to hematite. Clay Minerals 31, 63-74, 1996.

[26] S. Kuo, E.G. Lotse, Kinetics of phosphorus adsorption by calcium carbonate and Ca-kaolinite. Soil Sci. Soc. Am. Proc. $36,725-729,1972$

[27] H. Eyring, The activated complex in chemical reactions. J. Chem. Phys. 3, 107-115, 1935.

[28] [28] L. Madrid, A.M. Posner, Desorption of phosphorus from goethite. J. Soil Sci. 30, 697-707, 1979

[29] J.C. Ryden, J.K. Syers, J.R. McLaughlin, Effects of ionic strength on chemisorptions and potential-determining sorption of phosphorus by soils. J. Soil Sci. 28, 62-71, 1977.

[30] J.C. Ryden, J.K. Syers, Rationalisation of cation and ionic strength effects on P sorption by soils. J. Soil Sci. 26, 395-406, 1975 .

[31] J.C. Ryden, J.K. Syers, Charge relationships of phosphorus sorption. Nature, 255, 51-53, 1975

[32] R. Naidu, N.S. Bolan, R.S. Kookana, K.G. Tiller, Ionic-strength and $\mathrm{pH}$ effects on the sorption of cadmium and the surface charge of soils. Europ. J. Soil Sci. 45, 419-429, 1994.

[33] H.D. Ruan, R.J. Gilkes, Dehydroxylation of aluminous goethite: unit cell dimensions, crystal size and surface area. Clays Clay Minerals 43, 196-211, 1995.

[34] J. Torrent, Rapid and slow phosphorus sorption by Mediterranean soils: effect of iron oxides. Soil sci. Soc. Am J. 51, 78-82, 1987.

[35] J. Torrent, U. Schwertmann, V. Barron, Fast and slow phosphorus sorption by goethite-rich natural materials. Clays Clay Miner. 40, 14-21, 1992.

[36] I.R. Willett, C.J Chartres, T.T. Nguyen, Migration of phosphorus into aggregated particles of ferrihydrite. J. Soil Sci. 39, 275-282, 1988.

[37] C. Colombo, V. Barron, J. Torrent, Phosphorus adsorption and desorption in relation to morphology and crystal properties of synthetic hematites. Geochimica et cosmochimica Acta. 58, 1261-1269, 1994.

[38] M.T. Pardo, M.E. Guadalix, M.t. Garcia-Gonzalez, Effect of $\mathrm{pH}$ and background electrolyte on $\mathrm{P}$ sorption by variable charge soils. Geoderma, 54, 275-284, 1992.
[39] W. Espinoza, R.G. Gast, Jr. R.S. Adams, Charge characteristics and nitrate retention by two Andepts from Southe-Central Chile. Soil Science Society of America proceedings. 39, 842-846, 1975.

[40] A.S. Black, S.A. Waring, Adsorption of nitrate, chlorite and sulfate by some highly weathered soils from south-east Qeensland. Austr. J. .Soil Sci. Res. 17, 271-282 1979.

[41] N.J. Barrow, Reaction of anions and cations with variable-charge soils. Adv. Agron. 38, 183-228, 1985.

[42] P.A. Sanchez, G. Uehara, Management considerations fro acid soils with high phosphorus fixation capacity, in : F.E. Khasawneh, E.J. Kamprath (Eds.), The Role of Phosphorus in Agriculture, 1980, pp471-514.

[43] R.J. Haynes, Effects of liming on phosphorus availability in acid soils: a critical review. Plant and Soil. 68, 298-309, 1982.

[44] K.R. Helyar, D.N. Munns, R.G. Burau, Adsorption of phosphorus by gibbsite. II. Formation of surface complex involving divalent cations. J. Soil Sci. 27, 315-323, 1976.

[45] J.C. Ryden, J.K. Syers, Calcium retention in response to phosphorus adsorption by soils. Soil Sci. Soc. Am. J. 40, 845-846, 1976.

[46] J.C. Ryden, J.K. Syers, Rationalisation of cation and ionic strength effects on P sorption by soils. Journal of Soil Science. 26, 395-406, 1975

[47] D. Hawke, P.D. Carpenter, K.A. Hunter, competitive adsorption of phosphorus on goethite in marine electrolytes. Environ. Sci. Technol. 23, 187-191, 1989.

[48] D. Muljadi, A.M. Posner, J.P. Quirk, The mechanism of phosphorus adsorption by kaolinite, gibbsite, and pseudoboemite. J. Soil Sci. 17, 212-247, 1966.

[49] Y. Watanabe, H. Yamada, T. Kasama, J. Tanaka, Y. Komatsu, Y. Moriyoshi, Adsorption behavior of phosphorus on synthetic boehmites. Proceedings of the 19th International Japan-Korea Seminar on Ceramics, pp. 80-84, 2002.

[50] J.H. de Boer, The structure and Properties of Porous Materials. D.H. Everett and F.S. Stone, Eds. Butterworth, London, 1958.

[51] J.P. Quirk, Negative and positive adsorption of chloride by kaolinite. Nature, 188, 253-254, 1960.

[52] R.K. Schofield, H.R. Samson, The deflocculation of kaolinite suspensions and the accompanying change over from positive to negative chloride adsorption. Clay Min. Bull. 2, 45-51, 1953

[53] Y.S.R. Chen, J.N. Butler, W.J. Stumm, Kinetic studey of phosphorus reaction with aluminium oxide and kaolinite. Environ. Sci. Technol. 7, 327-332, 1973.

[54] F.J. Hingston, R.J. Atkinson, A.M. Posner, J.P. Quirk, Specific adsorption of anions. Nature (London). 215, 1459-1461, 1967

[55] F.J. Hingston, R.J. Atkinson, A.M. Posner, J.P. Quirk, Anion adsorption by goethite and gibbsite. J. Soil Sci. 25, 16-26, 1974.

[56] L. Sigg, W. Stumm, The interaction of anions and weak weak acids with the hydrous goethite $(\alpha-\mathrm{FeOOH})$ surface. Colloids Surf. 2, 101-117, 1981. 
[57] K.R. Helyar, D.N. Munns, R.G. Burau, Adsorption of phosphorus by gibbsite. I. Effects of neutral chloride salts of calcium, magnesium, sodium, and potassium. J. Soil Sci. 27, 307-314, 1976.

[58] J.K. Edzwald, D.C. Toensing, M.C.Y. Leung, Phosphate adsorption reactions with clay minerals. Environ. Sci. Technol., 10 (5), 485-490, 1976.

[59] G.W. Smilie, D. Curtin, J.K. Syers, Influence of exchangeable calcium on phosphorus retention by weakly acid soils. Soil Sci. Soc. Am. J. 51, 1169-1172, 1987.
[60] White and Taylor, Effect of $\mathrm{pH}$ on phosphorus adsorption and isotopic exchange in acid soils at low and high additions of soluble phosphorus. J. Soil Sci. 28, 48-61, 1977.

[61] P. Loganathan, W.J. Maier, (1975) Some surface chemical aspects in turbidity removal by sand filtration. Am Water Works Assoc. J. 67, 336-342.

[62] Rajan, S.S.S. and Fox, R.L. (1972) Phosphorus adsorption by soils. I. Influence of time and ions environmental on phosphorus adsorption. Common. Soil Sci. Plant Anal. 3, 492-504. 